\title{
Dialogic Narrative Discourse in Austen's Emma: A Bakhtinian Review
}

\author{
Soghra Nodeh \\ Department of Foreign Languages and Linguistics, Faculty of Literature and Humanities, Shiraz University, Pardis Eram, \\ Shiraz, IRAN \\ e-mail: Marzieh.nodeh@gmail.com,mn_afflatus@yahoo.com
}

\begin{abstract}
Due to the inherent multiple-voicedness of the genre of novel, novelists, via taking oppositional textual positions, can create twofold narratives which serve to convey two different intentions simultaneously, the direct intention of the character who is speaking and the refracted intention of the author. Such narratives could be created through using the disguise of carnivalesque character whose discourse is intentionally dialogized by means of an ironic discourse which embeds a potential unfolded dialogue of two (opposing) world views. Austen draws on such potential inherent in novelistic discourse by creating carnivalesque characters, layering of masquerades, and multiple mimesis to disguise her real intention. Following Bakhtin's theories of dialogism and carnivalesque, the present research investigates Austen's Emma through tracing carnivalesque character, extremely mocked by the objective narrator in the novel, who serves to disguise the real intention of the author and to create a double-voiced discourse leading the readers towards a double reading of the narrative.
\end{abstract}

Keywords: Austen, Emma, Bakhtin, dialogism, double-voiced discourse, carnivalesque character.

\section{INTRODUCTION}

The genre of novel has the potential to include plurality of voices in it through its inherent multiplevoicedness which is why, according to Bakhtin, in a novel "the voices from the margins are still present and can be heard by the attentive ear" (as cited in Kehde, 2001, p. 28). Moreover, novel, in contrast to the genre of poetry, which pays homage to the voice of authority, functions as an unofficial genre, during the era of Austen, which means that it functions as a genre that has the potentiality to resist the agents of authority and hierarchy dominating in the patriarchal society. Bakhtin, considering novel's historical relationship to parody, "relates it to the tradition of carnival, by which he means the great festivals temporarily inverting the power of hierarchy." Therefore, he believes that novel, as an unofficial genre, has the potential of creating carnival of laughter and thus challenging powers of authority by means of parody. Bakhtin's concept of carnival could be applied in literary works in which the reader does not think that the author intended any carnivalesque or parodic effect. Through this method, authors can give voice to the marginalized figures, whose voices are most of the time either "internalized" or "misunderstood," while speaking against the authority (Kehde, 2001, p. 2829). Due to such essential potentials existing within the genre of novel, the concept of novel has been closely interrelated with the concept of woman from the very beginning of this genre's appearance in the world of literature. The reason is that in a patriarchal society women's voices are suppressed by the Law of the Father; hence, they cannot articulate their criticism against such a male-centered system of government. Thus, with the rise of novel, having so many potentials for indirect criticism, women took refuge to this genre for expressing their often suppressed ideas. Austen, as a female writer, draws on such potentials inherent in novelistic discourse in order to mask her criticisms against patriarchy. This is while some critics believe that Austen's novels belong to "one class of partisan novels, the conservative;" Daugherty (2004), for instance, gives the example of Emma as one of Austen's literary works which belong to that category of novels named as "orthodox" (p. 123). However, the important fact is that the climate of Austen's time was unwelcoming for female inventiveness; therefore, due to the specific situation of her time, Austen set to experience with unprecedented literary innovations, which let her text both to conform to the patriarchal society in which she lived and the supports of which she needed for publication of her works, through creating a subversive text inverting the policies of patriarchy against women by giving voice to the marginalized characters through the submissive disguise of the narrative of patriarchy. The present research, via employing Bakhtin's 
theories of carnival and dialogism, aims at explicating Austen's Emma and the methods through which the author creates a double-voiced discourse in a text which is submissive at the superficial level but subversive at the hidden level.

\section{DISCUSSION}

Austen disguises her real voice and intention, to use Bakhtin's words (1981), "through a layering of masquerades, a multiple mimesis," which is the essence of the concept of "heteroglossia" that Bakhtin defines as "words-with-a loophole, word-with-a-sidewardsglance" (p. xxi). While disguising herself as an Angel in the House through her narrator who renovates her authorial voice and stance, Austen masquerades her feminist message in the voice or even in the silences of her marginalized characters. She makes use of her female characters for communicating specific political implications for social construction.

Hence, Austen takes "oppositional textual positions," that is, the role the dutiful narrator wearing a feminine mask and a monstrous female who "give[s] the masquerade in excess" (Heath, 2003, p. 57). Through using such masquerades, Austen creates a doublevoiced narrative which leads the readers to have a double reading and a double interpretation of the narrative. Such a model of narrative goes with Bakhtin's theories of discourse in novel. A rebellious author, Bakhtin (1981) believes, puts on a disguise "that could serve to define the position from which he views life, as well as the position from which he makes that life public" (p. 161). Therefore, he asserts that if readers fail to understand the doublevoicedness of the narrative and, therefore, only listen to the voice of the narrator, they will miss the author's subversive intentions and thus will fail to come to an appropriate interpretation of the novel.

Behind the narrator's story we read a second story, the author's story; he is the one who tells us how the narrator tells stories, and also tells us about the narrator himself. We acutely sense two levels at each moment in the story; one, the level of the narrator, a belief system filled with his objects, meaning and emotional expressions, and the other, the level of the author, who speaks (albeit in a refracted way) by means of this story and through this story. [...] if one fails to sense the second level, the intensions and the accents of the author himself, then one has failed to understand the work. (Bakhtin, 1981, p. 314).

This is the case with Austen's novels. As Todd (2006) points out, in Austen "nothing is quite what it seems at first" (p. 45). Her real intention is hidden behind the voice of the narrator who mocks the comic female character used as a mask for giving voice to the author's criticisms. Bakhtin (1981) asserts that the voice of the author is not to be found in the narrator's commentary but it emanates in a refracted way, through the disguise of "the clown and the fool (transformed in various ways)" (p. 161). Austen uses such a disguise of clown or fool for conveying her criticism against her contemporary society. She, Bradley (1981) believes, reminds us of Shakespeare when she portrays minor comic characters who are objects of our laughter but behind the humor which causes this laughter, she provides us with her real ideas and criticisms (p. 37).

Comedy is a way of escaping from confinement and a way of breaking down the restrictions put upon people in order to suppress them. Shaftesbury (2012) notes,

The natural free spirits of ingenious men, if imprisoned and controlled, will find out other ways of motion to relieve themselves in their constraints; and whether to be in burlesque, mimicry, or buffoonery, they will be glad at any rate to vent themselves, and be revenged on their constrainers. (p. 50)

Therefore, female authors such as Austen, due to the repressive attitude of male-centered society towards women, prefer to give voice to their radical views against patriarchy "through the mouths of comic characters." She uses minor women characters such as Mrs. Bennet (in Pride and Prejudice), Charlotte Palmer (in Sense and Sensibility), and Miss Bates (in Emma to which novel the current analysis is devoted to) who, functioning as a trickster, under the mask of comedy "defy all rules of conduct, mocking male authority, and laughing as they do so" (Bilger, 2004, p. 89).

This is precisely the function of Bakhtinian fool. Bakhtinian fool is a comic character who is extremely mocked by the objective narrator but, as a matter of fact, is used as a mask for the author to criticize society. Bakhtin (1981) believes that "the author needs the fool: by his very uncomprehending presence he makes strange the world of social conventionality" (p. 404). They create ambivalent laughter which, according to Herndl (2003), "is a dialogic laughter since it is 'at the same time cheerful and annihilating.' It is both festive and mocking; it is directed at everyone, those in power and those subjected to it" (p. 9). This is one of the best means through which the female authors in a patriarchal society give voice to their criticisms. They have no other choice to express their intentions but through 
using a "refracted masculine-defined" narrative (Russo, 2007, p. 18). Hence, they employ a comic female character who is the object of laughter and mockery for the male reader while behind such a comic portrait they hide their criticisms against patriarchy for belittling women to such comic bores.

Ty (2004), in her study of women's romances, points out that in some of these writings the reader deals with a "twofold narrative" which serves to convey two different intentions, that is, the direct intention of the character who is speaking, and the refracted intention of the author (p. 98). A hysteric, functioning as a trickster, is a figure of a fool who functions as a conforming individual to her role in patriarchy while at the same time creating a critique of the role that is defined for her and thus creating a "twofold narrative". The figure of a hysteric, who is the most marginal of figures in patriarchy, is the best model of character for creating such a double-voiced discourse to criticize the Law of the Father. The female hysteric characters, at the same time that they are conforming to the role imposed on them, subvert the standards set for women by patriarchal society. The woman novelist "must be a hysteric. Hysteria [...] is simultaneously what a woman can do both to be feminine and to refuse femininity, within patriarchal discourse" (Mitchell, 2005, p. 101).

Austen makes use of such hysteric characters and transforms them to the figure of an old maid who is the central cause of laughter in masculine satiric conventions. In Emma, which is the focus of the present study, she uses Miss Bates' "creative hysteria" in order to challenge patriarchy (Gilbert and Gubar, 2001, p. xv). In the depiction of Miss Bates' character, Austen employs narrative techniques of "repetitions, lateralization, ruptures, and discontinuity" and in this way she portrays an old spinster who is destined to be ridiculed in the rational stance of the Law of the Father, "the standpoint of reason" (Irigaray, 1985, p. 163). She is depicted as an unacceptable and embarrassing character. The sketch of this character, as a stupid and excessively talkative woman who always talks at wrong times, goes with the role prescribed for women by patriarchy. However, paradoxically enough, this character, at the same time that she conforms to the feminine role prescribed for her, is used by the author for condemning patriarchy for imposing such roles on women.

An example of Miss Bates' foolish incessant talking could be found in the part she enters the ball at the Crown Inn:

So very obliging of you!- no vain at all. Quite thick shoes. And Jane declares- well!- (as soon as she was within the door) well! This is admirable!- excellently contrived, upon my word. Nothing wanting. Could not have imagined it.- so well lighted up!- Jane, Jane, look!- did you ever see anything? Oh! Mr. Weston, you must really have had Aladdin's lamp. Good Mrs. Stokes would not know her own room again. I saw her as I came in; she was standing in the entrance. 'Oh! Mrs. Stokes,' said I- but I had not time for more.' (Austen, 2008, p. 322)

Here Austen uses few formal punctuations as Miss Bates speaks, a strategy which puts emphasis on "the relentlessness nature of her talking" and which serves to exaggerate her mask of femininity leading to her being ridiculed by the ignorant patriarchal reader (Hall, 2009, p. 195). Luce Irigaray (1985) proposes the use of a "hysteric's exaggerated masquerade of the feminine" in order to bring patriarchal structure and the role it imposes on women under question. For a reader to understand what lies behind the portrayal of this character, Irigaray notes, one would have to "listen with another ear, as if hearing an 'other meaning' always in the process of weaving itself, of embracing itself with words, but also of getting rid of words in order to become fixed, congealed in them" (p. 163). This is what could be traced in narrative strategy employed in Emma. Through using such comic characters as Miss Bates, whom the other voices in the narrative mock, Austen creates a carnival which Bakhtin (1984) defines as a way of "temporary liberation from the prevailing truth and from the established order," a way of "suspension of all hierarchical rank, privileges, norms and prohibitions" (p. 10). While pretending to tell one story which is articulated through the mouth of the narrator who mocks the comic Miss Bates, Austen tells another story with overtones of rebellion against the hierarchy through the mouth of the comic female character and thus creates a double-voiced narrative or what Bakhtin (1981) dubs as "heteroglosic" discourse:

Heteroglosia, once incorporated into the novel $[\ldots]$ is another's speech in another's language, serving to express authorial intentions but in a refracted way. Such speech constitutes a special double-voiced discourse. It serves two speakers at the same time and expresses simultaneously two different intentions. [...] Double-voiced discourse is always intentionally dialogized. Examples of this would be comic, ironic or parodic discourse, the refracting discourse of a narrator, refracting discourse in the language of a character and finally discourse of a whole incorporated genre - all these discourses are 
double-voiced and internally dialogized. A potential dialogue is embedded in them, as yet unfolded, a concentrated dialogue of two voices, two world views, two languages. (p. 324-325).

Dialogism pinpoints and puts emphasis on otherness and difference. Speaking from the place of the Other, Herndl (2003) believes, brings about a striking difference between female use of language and the male one. This feminine language, as defined by patriarchy, which is apparent in Miss Bates' language, is "contralogic" in the eyes of the patriarchal male reader, that is, it does not go with the "solid male rules of logic, clarity, consistency" (p. 11).

She was now met by Mrs. Weston. 'Very well, I thank you, ma'am. I hope you are quite well. Very happy to hear it. So afraid you might have a headache! Seeing you pass by so often, and knowing how much trouble you must have. Delighted to hear it indeed. Ah! dear Mrs. Elton, so obliged to you for the carriage! Excellent time. Jane and I quite ready. Did not keep the horses a moment. Most comfortable carriage. Oh! And I am sure our thanks are due to you, Mrs. Weston, on that score. Mrs. Elton had most kindly sent Jane a note, or we should have been. But two such offers in one day! Never were such neighbours. I said to my mother, 'Upon my word, ma'am --.' Thank you, my mother is remarkably well. Gone to Mr. Woodhouse's. I made her take her shawl - for the evenings are not warm -- her large new shawl -- Mrs. Dixon's wedding present. So kind of her to think of my mother! Bought at Weymouth, you know -- Mr. Dixon's choice.' (Austen, 2008, p. 137).

She may seem inconsistent, illogical, and even ridiculous from the patriarchal viewpoint of reason but the fact is that this is only an exaggerated mask used by the female author for disguising her criticism against patriarchy. As Moi (2002) maintains, a feminist writer's job "is a theatrical staging of the mime: miming the miming imposed on woman, $[\ldots]$ (her mimicry mirrors that of all women) [a specularization that] intends to undo the effects of phallocentric discourse simply by overdoing it" (p. 140). Therefore, Austen uses the masquerade as a compliant example of a feminine who plays the role imposed on her as a woman by the patriarchal system but who is, in fact, setting a hidden rebellion against such system.

Bakhtin (1981) asserts that the novelist stands in need of some essential, "formal and generic mask that could serve to define the position from which he views life $[\ldots]$ and it is precisely here, of course, that the masks of the clown and the fool transformed in various ways come to the aide of the novelist" (p. 161). Bakhtin's theory of discourse in novel describes a "multivoiced or polyphonic resistance to hierarchies and laughter at authority" (Herndl, 2003, p. 8). This is what could be detected in Austen's portrayal of such comic female characters as Miss Bates. These characters' healthy failure to understand the conventions and rules set for women by the Law of the Father, serves to challenge the hierarchies and discriminations which allow separation and marginalization. Austen acts as a trickster writer who at the surface level seems to be creating a stereotypical fool as a character but who at the hidden level has created a trickster who is more of an idiot sage with an obsession to resist and even protest against restrictions imposed on the socially disempowered.

A trickster revolts against the authority without seeming to do so. Austen, hiding behind the disguise of the narrator, is only superficially going with the expectations of the dominant patriarchal structure in laughing at the comic female character that is the object of laughter for the patriarchal reader. In a deeper outlook one can observe that she is attacking the ideology that leads to such derision on the part of men towards women. If a reader laughs at Austen's comic female character, the reason is that she can perfectly play the role that is prescribed for her, that is, a whiner fool. Therefore, depiction of such comic women, as a matter of fact, is a criticism of the social order which enforces these women to adopt such a ridiculous posture in order to survive in a hostile environment.

The figure of female trickster, here the apparently stupid and talkative Miss Bates, is the opposite of the figure of Angel in the House: "She is outspoken; she makes people uncomfortable; she willfully violates codes of female behavior; and above all she laughs." Like the folktale characters, such female tricksters as Miss Bates "offer a vicarious victory over restrictive forces." The comic Miss Bates transcends the rules of patriarchy, makes fun of them, and "effectively slay[s] the angel figure with [her] iconoclastic laughter." Hence, such female authors as Austen, through using a comic disguise for characters who articulate their criticisms against the Law of the Father achieve safety; since, at the same time that they challenge the Law of the Father, these comic characters have the capacity "to give the last laugh on their male opponents" (Bilger, 2004, p. 98). The author is thus satisfied with the trickster's violation of the rules of society. She is revenged by the comic character who challenges the repressive power of the male authority without bringing any risk for the author; she 
"commit[s] the violation only vicariously" (Eco, 1984, p. 2).

Austen discerns her objection to the patriarchal society by the use of monstrous caricatures of subordinates in a patriarchal society. She depicts female characters who exaggerate their "prescribed feminine role[s] as to be laughable, a hoyden traipsing around town in a borrowed gown." These characters through laughter, talkativeness, droning, or even stupidity "'carnivalize' the dominant direction of the novel." As Russo (2007) observes "these voices of carnival resist, exaggerate, and destabilize the distinctions and boundaries that mark and maintain high culture and organized society" (p. 6). Through wearing the mask of femininity, the comic female character, instead of confirming the prescribed feminine role, makes fun of the law of patriarchy. Such female characters, using a double mimesis, do not merely create laughter but wonder, wonder about the conventional frames of feminized novel. While the objective third person narrator imposes her rational ideas on the narrative, such comic female characters as Miss Bates disrupt the discourse with comments and actions that seem unacceptable or even embarrassing. The character serves to render the real predicament which is played out on the margins of society.

Davies (2008) in his sociological study of "stupidity jokes" maintains that the powerful people consider these jokes as an affirmation of their superior status while the powerless consider them as pointing out the "absurdities of the power structure." The creator of these jokes, mostly from marginalized and powerless groups of society, taking a conservative stance by the use of such "ambiguous humor," enjoys playing with the forbidden ideas. (p. 181-2) Accordingly, through this method Austen challenges "male-centered authority by making fun of absurd conduct rules of behavior and assumptions about women's nature" (Bilger, 2004, p. 116).

Thus, the persistent attitude that underlies feminist humor is that of social revolution; in other words, the feminist writer is ridiculing a social system "that can be, that must be changed" (Kaufman, 2006, p. 13). Austen uses subversive comedy in her novels in order to be able to "contribute to the ongoing debate about women's proper place in society" through criticizing eighteenth century gender politics. This is an ingenious way for a rebellious author to give word to ideas which are otherwise offensive (Bilger, 2004, p. 9). Austen's comic female characters speak or act in a way that is at odds with what their society considers as proper for a woman. Miss Bates, through her language, tramples on what other women consider as decorum and enters into areas that other women avoid: "I know I do sometimes pop out a thing before I am aware. I am a talker, you know; I am rather a talker; and now and then I have let a thing escape me which I should not" (Austen, 2008, p. 314). She does not remain silent about the insults and mentions them before she is aware, though it seems improper in the eyes of the society. She disguises her real intention behind a feminine mask of ignorance. Through double talks Miss Bates subversively breaks the rules of feminine behavior set by the patriarchal culture.

Looking from another perspective, Hall (2009) maintains that Miss Bates, as an unmarried woman who is being marginalized by the patriarchal society which considers being a wife and a mother as the only important role of a woman in society, tries to control the conversations "in order to retain the stage" and "avoid sinking into complete obscurity." She tries to establish and legitimize herself in Highbury society through her incessant talking (p. 193). She intends to be the sole speaker in order to attract the attention of all people around. That is why she is so much disappointed when she understands that Mr. Knightly already knows about Mr. Elton's engagement, the news which she is going to break to the Highbury society in order to attract attention of the others.

'But where could you hear it?,' Cried Miss Bates, 'where could you possibly hear it Mr. Knightly? For it is not five minutes since I received Mrs. Cole's note- no it cannot be more than five- or at least ten- for I had got my bonnet and spencer on, just ready to come out.' (Austen, 2008, p. 173).

The pages of the novel are so much flourished by Miss Bates' conversations that even the reader may want to "skip over Miss Bates' speeches" (Hall, 2009, p. 193-4). Austen pulls the reader into inattention in order to portray the lack of attention with which such a woman as Miss Bates deals in a patriarchal society.

In the Crown Inn hall, while in her incessant talking she continues commenting on everything she finds around, including luxury and décor of the hall, she mentions a very illuminating point about her condition.

'Well, this is brilliant! I am all amazement.' Could not have supposed anything!- such elegance and profusion!- I have seen nothing like it since- well, where shall we sit? Where shall we sit? Anywhere, so that Jane is not a draught. Where I sit is of no consequence.' (Austen, 2008, p. 330)

Miss Bates is aware of her status in such society; she is "of no consequence," but she struggles to find a 
place for herself by taking hold of the conversations. As a poor unmarried woman, she does not have "an independent role in her society [...], she must continually force her way into the story" through her continual gossiping. Thus, Miss Bates' desire for constant chatter reflects the confinement of her life (Hall, 2009, p. 175-176). On the superficial level, she seems to be a one-track minded character that goes on chattering and gossiping without restraint. However, this tendency to be a great talker is only for the sake of survival in a society which pushes her to margins. In this line, Todd (2006) asserts, Miss Bates' stuttering, tedious speech may sometimes suggest the choking of repressed feelings in a male-dominated society ( $\mathrm{p}$. 103-4). Therefore, by creating the superficial mask of a talkative comic fool through Miss Bates, Austen condemns patriarchy for marginalizing and suppressing the voices of women and creating such horrific status for them. There is a part in Emma in which Miss Bates, leading a group of women up the stairs to her home, refers to her appalling status:

Pray take care, Mrs. Weston, there is a step at the turning. Pray take care, Miss Woodhouse, ours is rather a dark staircase- rather darker and narrower than one would wish. Miss Smith, pray take care. Miss Woodhouse, I am quite concerned. I am sure you hit your foot. Miss Smith, the step at the turning. (Austen, 2008, p. 238).

Behind the seemingly ridiculous repeated warnings here, there is a trace of the real female predicament within hostile patriarchal environment, a dark and dangerous staircase. Furthermore, by plural form of words that she uses most of the time, Miss Bates is giving an account of the dangerous situation of all women, not only that of her own. Austen, through the mouth of this comic character, criticizes the status of not only such women as Miss Bates but that of all women in a patriarchal society.

\section{CONCLUSION}

Women belong to that layer of society in which voices are almost always suppressed. Their exclusion from the dominant voice and power in a patriarchal society brings about "a systematic and fundamental difference in the kind of art women make and the ways women think and the ways women use language." A female author's speech is "'an-other's' speech, serving 'an-other's' language. A feminine language lives on the boundary. A feminine text overthrows the hierarchies" (Herndl, 2003, p. 10). Therefore, feminine texts should not be considered as monologic texts allowing only one speaker, the narrator, speaking as the voice of the author and that of the authoritarians. Rather they allow the voices from the margins to overthrow the dominant discourse through their deceptively submissive discourse.

Austen, belonging to this category of writers, employs an apparently conservative but ingenious method of narration which covertly provokes a harsh criticism against patriarchy. Like Miss Bates, she attacks patriarchy through a superficially comic narrative which functions as a humorous but rebellious narrative. Through creating carnivalesque characters, a layering of masquerades, and multiple mimesis, Austen takes oppositional textual positions creating a twofold narrative which serves to convey two different intentions simultaneously, that of the character who is speaking and that of the author disguised as clown. Austen's real voice is not to be found in the narrator's commentary but in the "disguise of clown" or carnivalesque character of Miss Bates by the presence of whom Austen creates a twofold narrative which allows a concentrated dialogue of two voices, two world views, and two languages (Bakhtin, 1981, p. 325). Austen through drawing on such strategies disguises her real intention and creates a doublevoiced discourse leading the readers towards a double reading of the narrative. Her text is a dialogic text in which, like the voices Bakhtin hears in the novel's carnival, the female voice secretly laughs at the authority.

\section{REFERENCES}

Austen, J. (2008). Emma. Oxford: Oxford University Press.

Bakhtin, M. (1981). The dialogic imagination. Austin: University of Texas Press.

Bakhtin, M. (1984). Rabelais and his world. Bloomington: Indiana University Press.

Bilger, A. (2004). Laughing feminism: Subversive comedy in Frances Burney, Maria Edgeworth, and Jane Austen. Detroit: Wayne State University Press.

Bradley, A. C. (1981). Jane Austen. In L. Lanzen (Ed.), NCLC (Vol. 1) (pp. 37-38). Harris, Detroit: Gale Research Inc.

Daugherty, M. G. (2004). Creative discourse in the eighteenth century courtship novel. (Doctoral dissertation). Available from ProQuest Dissertations \& Theses Database. (AAT 3123974)

Davies, C. (2008). Jokes and their relation to society. Berlin: Mouton de Gruyter.

Eco, U. (1984). The frames of comic 'freedom.' In T. A. Sebeok (Ed.), Carnival (pp. 1-9). New York: Mouton.

Gilbert, S. M. \& Gubar, S. (2001). The madwoman in the attic: The woman writer and the nineteenthcentury literary imagination. New Haven: Yale University Press. 
Hall, L. A. (2009). Grounding the figure of the heroine: The 'other women' in Jane Austen's novels. (Doctoral dissertation). Available from ProQuest Dissertations \& Theses Database. (AAT 3363870)

Heath, S. (2003). Joan Riviere and the masquerade. In V. Burgin, J. Donald and C. Kaplan (Eds.), Formations and fantasy (pp. 44-61). London and New York: Methuen.

Herndl, D. P. (2003). The dilemmas of a feminine dialogic. In D. M. Bauer (Ed.), Feminism, Bakhtin, and the dialogic. (pp. 7-24). Albany: New York University Press.

Irigaray, L. (1985). This sex which is not one. Ithaca: Cornell University Press.

Kaufman, G. (2006). Pulling our own strings: Feminist humor and satire. Bloomington: Indiana University Press.

Kehde, S. (2001). Voices from the margin: Bag ladies and others. In D. M. Bauer (Ed.), Feminism, Bakhtin, and the dialogic. (pp. 25-38). Albany: New York University Press.
Mitchell, J. (2005). Women: The longest revolution. New York: Doubleday.

Moi, T. (2002). Sexual/textual politics: Feminist literary theory. London: Routledge.

Russo, M. (2007). Female grotesques: Carnival and theory. Milwaukee: University of Wisconsin Center for Twentieth Century Studies.

Shaftesbury, A. (2012). Sensus communis, an essay on the freedom of wit and humour in a letter to a friend. In L. E. Klein (Ed.), Characteristics of men, manners, opinions, times (pp. 29-70). New York: Cambridge University Press.

Todd, J. (2006). Cambridge introduction to Jane Austen. New York: Cambridge University Press.

Ty, E. (2004). Desire and temptation: Dialogism and the carnivalesque. In H. Karen and H. Wussow (Eds.), Category romances. A dialogue of voices: Feminine literary practice and Bakhtin (pp. 97113). London: University of Minnesota Press. 